\title{
Sustainable Viticulture Practices on the Face of Climate Change
}

\author{
Ali Sabir ${ }^{*}$, Alper Kucukbasmaci², Merve Taytak², Omer Faruk Bilgin², Akram Ibrahim Mohammed Jawshle², \\ Orhan Jamal Mohammed Mohammed ${ }^{2}$ and Yasin Gayretli ${ }^{2}$ \\ ${ }^{1}$ Horticulture Department, Selcuk University, Turkey \\ ${ }^{2}$ Selcuk University Graduate School of Natural and Applied Science, Turkey
}

Submission: June 09, 2018, Published: September 11, 2018

*Corresponding author: Ali Sabir, Selcuk University Agriculture Faculty Horticulture Department, 42075 Konya, Turkey; Tel: 905334620261 ; Email: asabir@selcuk.edu.tr

\begin{abstract}
Change in past climate is evidenced to alter regional temperature and precipitation, resulting in non-neglectable influences on agricultural activities and crop production. In viticulture, climate change can cause multiple co-occurring changes in cultural conditions, growing seasons, environmental conditions, winter frost, vine phenology, grape berry composition, biotic disturbance, and abiotic disturbance. In order to alleviate the negative effects of climate change, the use of adapted genotypes is a better tool as it has the advantage of being environmentally friendly and cost effective. Besides, many other cultural practices should be employed simultaneously to obtain better results.
\end{abstract}

Keywords: Grape growing; Drought; Environment; Cultural practices

\section{Introduction}

Grapes (Vitis vinifera L.), belonging to the family Vitaceae, comprise about 60 species distributed in Asia, North America and Europe under subtropical, Mediterranean and temperate climatic conditions. Vitis vinifera $L$. has acquired significant economic interest over the history while some other species such as $V$. berlandieri, $V$. riparia and $V$. rupestris have been used to breed rootstocks. Thousands of cultivars classified as Vitis vinifera $L$. subsp. Sativa are widely cultivated for fresh fruit, raisin (dried grape berries), juice and mainly for wine [1,2]. Domestication of the grapevine appears to have occurred between the seventh and the fourth millennia BC, in an area between the Black Sea and Iran $[3,4]$. Domesticated genotypes have been spread by humans to the Near East, Middle East and Central Europe.

Previously, grape growers cultivated predominantly traditionally grown local grape cultivars [5], because of their high suitability to local ecological conditions. Later, in the second half of the nineteenth century, intensive renovation of vineyards took place and indigenous varieties were mostly replaced by several worldwide cultivars [6]. Grapevines are believed to possess notable climate adaptability. Nonetheless, specific climatic conditions are necessitated for well-balanced berry maturation and high-quality grape production. Accumulated temperatures above $10{ }^{\circ} \mathrm{C}$ (base temperature) are required for grapevine growing onset [7]. Grape growers have adapted varieties and viticulture management activities throughout the centuries to keep harvests within desired dates. However, the climate throughout the world is constantly changing. Agricultural productivity of an area is directly correlated with climate and several modeling tools and approaches are already in place that could be used to predict the effects of climate change using bioclimatic parameters. Climate change induced increases in temperature are projected to negatively affect ecosystems but other species might respond positively [8]. Changes in climate conditions and, especially, in rainfall regime are therefore likely to alter agricultural practices including irrigation and transport of nutrients and pesticides in the environment. Adopting cultural practices is the first option to reduce adverse climatic effects [9].

This paper presents a review of general impacts of climate change on viticulture and cultural applications to combat adverse effects of climate change. There are many mitigation opportunities in the agricultural sector. This article is intended to help growers understand the relative magnitude and feasibility of mitigation opportunities.

\section{General Effects of Climate Change on Grapevines Growth}

Climate change is commonly considered as temperature increase and subsequent drought. Other factors such as increased atmospheric carbon dioxide $\left(\mathrm{CO}_{2}\right)$, increased radiation, wildfires, extreme weather and flooding and sea level rise should be considered. Increased environment temperature triggers advanced vine phenology, the date on which bud break, flowering, 
and véraison (onset of ripening) happen. This shifts the berry maturation phase to warmer periods in the summer, which will adversely affect grape composition, in particular with respect to aroma compounds. Early harvest dates under dry conditions are incompatible with the production of great terroir grapes or wines. Certain secondary metabolites, like anthocyanins, are negatively affected by high temperature. Grape acidity, in particular the malic acid content, decreases in high temperature [10]. Increased water stress due to high temperature impairs photosynthesis, reduces yields and modulates the berry must composition as already reported by researchers $[11,12]$. Studies imply that the frequency of extreme climatic events is likely to increase. This may have positive or negative implications on grape and wine quality depending on the region and the magnitude of change.

According to the IPCC's 2007 report, the average temperature has been increased by approximately $0.5^{\circ} \mathrm{C}$ in the $20^{\text {th }}$ century and McCarl [13] indicated that further increase in global climate can be up to $1.4^{\circ} \mathrm{C}$ to $5.8^{\circ} \mathrm{C}$ by the end of the $21^{\text {st }}$ century. Higher temperatures modify the rainfall patterns, increase evapotranspiration and radiation. High radiation causes sunburn on grapes, particularly in the prevéraison phase. To deal with climate change, adaptation strategies are needed to continue to produce high quality grapes/wines and to preserve their features according to their origin in a changing climate.

\section{Changes in Plant Diseases and Pests}

Changes in climate and atmospheric gas composition influence severity and biology of plant diseases and pests. Higher temperature inevitably favours the dominance in certain plant pathogens since the increasing atmospheric $\mathrm{CO}_{2}$ concentration will directly increase the amounts of pathogen inoculum. It is evident from the studies that there is increased production of Fusarium biomass per unit wheat tissue at elevated $\mathrm{CO}_{2}$, which will increase inoculum transfer between successive growing seasons [14]. Studies on plant diseases also show that extreme weather events such as hurricanes causing the spread of plant pathogens to new agricultural lands are frequently occurred [15]. Such events may increase with the projected increase in the frequency of extreme weather events under climate change.Effect of climate change on agricultural pests has been studied by biologists. Studies revealed that insect pest activity, the second major cause of damage to crops, will increase in line with climate change leading to greater risk of crop losses [16]. Although science currently allows only very crude predictions of pest behavior, possibility of exotic pest invasion due to climate change should be considered when interpreting any estimates of the impacts of climate change.

\section{Strategies to Mitigate Adverse Effects of Climate Change}

In the following sections, we summarize the potentially feasible strategies to mitigate adverse effects of climate change.

\section{Adapting plant genotypes}

Grape growers need to implement adaptive strategies and practices to continue the production of high-quality grapes at economically acceptable yields in a warmer and dryer climate. Among various options, the use of adapted plant material is one of the better tools, because it has the advantage of being environmentally friendly and cost effective. Rootstock resistance to water deficits is highly variable [17]. Certain rootstocks, like 445M, 140 Ruggeri or 110 Richter, are known as highly tolerant to drought. In studies, creating new rootstocks that display greater resistance to drought is one of the priorities of today's viticultural research. Similarly, there are large differences in drought tolerance among grapevine varieties [18]. The notable advantage of adapting vineyards to increased drought stress through the choice of plant genotypes is that it is environmentally friendly and cost effective. When the climate becomes too warm, clonal selection should be oriented toward late-ripening clones using traditional varieties.

\section{Training systems}

Vine training can be modified to delay phenology. For example, higher trunks can reduce the temperature in the bunch zone and, therefore, limit maximum temperatures on dry soils. Late pruning may delay bud break and subsequent phenological stages. In this context, over centuries growers in Mediterranean region have developed a the so-called goble training system (Mediterranean bush vines) that allows a greater drought-resistant performance as the system limits vine water consumption while preventing water runoff from soil surface near the trunk.

\section{Cover crops}

Cover crops promote soil carbon sequestration and promote nitrogen retention in the cultivated soil. Studies have demonstrated that cover crops had enhanced the soil structural stability, the water holding capacity, the infiltration rate and the saturated hydraulic conductivity [19]. Legume plants as cover crop may play an important role by adding more atmospheric $\mathrm{N}_{2}$ through fixation into the soil. Quantitative evidence about the effect of cover crop in irrigated systems in semi-arid areas is lacking but necessary to understand the effect of cover crop on the mitigation of climate change and the improvement of agricultural soil quality. Cover crops can minimize the runoff water and thus can be considered as a proxy for minimizing potential erosion.

\section{Crushing pruning canes}

Vineyard pruning waste is the residue after pruning the vineyard trees, such as thin and thick branches, that is usually burned by the small-scale producers, contributing to global warming by the emission of greenhouse gases like $\mathrm{CO}_{2}$ during their combustion. Instead of burning, incorporation of the pruning canes in the soil can enhance soil properties and can be environment-friendly. Vineyard pruning residue generates over 1 ton of biomass waste per hectare [20]. These residues are suitable for energy valorization and are mainly composed of cellulose and lignin with a low moisture content.

\section{Irrigation management}

Achieving optimal water levels throughout the vegetation period requires precise control of irrigation water. This intervention can only be applied to irrigated systems and requires 
technical knowledge. High-efficient irrigation systems should be considered such as drip irrigation using soil moisture probes, pressure pump and climatic data [21]. Use of drip irrigation under plastic mulched conditions can be strongly recommended in semiarid soils [22]. The special soil environment under plastic mulched drip irrigation condition may also be highly beneficial for microbial growth owing to the better water and temperature environment.

\section{Precision fertilizer}

Overuse of synthetic fertilizers is a significant issue in most countries with highly industrialized, high-input agricultural systems. Increasing the efficiency of nutrient use is one of the essential approaches to alleviate negative effects of climate change. Fertilizers should be applied only as much as can be taken up by the crop. Injecting the nutrients on proper time into the soil near to plant roots instead of broadcasting would be efficient.

\section{Management of farmyard manure}

Improving stored manure practices in industrialized livestock systems. Farmyard manure presents no serious food security risks, if properly used, and have other co-benefits such as keeping the quality of agricultural water. These nutrients often become a source of emission, water and air pollution when handled improperly. One of the leading mitigation opportunities for stored manure is anaerobic digestion. There are quite a few simple storage and handling practices that can reduce emissions and pollution. Emissions from stored manure can be effciently reduced by covering the manure and keeping the manure in beds. Use of manure can reduce the need for synthetic fertilizer, reduce nutrient loading into ground and surface water bodies, and increase the productivity of croplands and pastures.

\section{Crop residue management}

Adoption of recommended management practices on agricultural soils can enhance carbon sequestration and reduce the rate of enrichment of atmospheric $\mathrm{CO}_{2}$. Application of crop residue as organic mulch may maintain soil moisture content, influence the soil organic carbon pools and also different management interventions like application of irrigation and nitrogen promote root growth. Organic mulch can also improve soil physical properties and growth of plants [23] while restricting the compatible weed growth.

\section{Ever-green screening plants}

Fast-growing, evergreen, hedging plants, like Leylandii, can protect the plants from heavy storm and cold winds. Use of screening plants is generally the cheapest way of forming an evergreen hedge and hence the most popular. Leylandii with its dense foliage is also very tolerant of wind and cold temperatures. It can serve as sound barrier and is best at filtering particulates (air pollution) from a passing traffic [24].

\section{Shade netting}

As the climate is getting warmer, grapevines have been showing potentially different responses to temperature and light. In arid and semiarid regions, certain grape cultivars, like 'Italia', usually experience sunburn problem. Shade netting is required to protect clusters and vines from excessive radiation and temperature. Use of nets also protects the summer shoots against hail damage and ripening berries from bird attack.

\section{Vineyards at higher altitudes}

Global climate change, warming in particular is expected to decrease sensory quality of horticultural crops. Environmental factors have been acknowledged to greatly influence grape and wine aromas. Wines produced from the highest site were preferred in tasting trials for their more patent floral notes and elegance [25]. In the lower sites, grapes at harvest accumulate lower amounts of all of the main classes of aroma compounds. But, wines produced from the highest site are preferred in tasting trials for their more patent floral notes and elegance. Thus, replacement of vineyard to higher altitudes and mountainous regions is expected to improve sensory quality of grapes although such adaptations have a high social and economic cost.

\section{Use of bioenergy}

Overconsumption of energy and excessive discretionary food intake inflates dietary greenhouse gas emissions. Bioenergy is generally considered to mitigate climate change by sequestering carbon dioxide $\left(\mathrm{CO}_{2}\right)$ emissions, and to enhance energy security by providing domestically produced energy. Biomass is believed to be a key future renewable energy source that can replace fossil energy. Exploitation of biomass as renewable energy source by the spouted beds technology may be considered an alternative that guarantees sustainable development and a clean process. Energy generation using biomass feedstocks has many benefits and has important advantages that reduce reliance on imported fossil fuels and alleviate greenhouse gas emissions. The selection of suitable and favorable locations for biomass plants becomes a crucial issue and concern because biomass feedstocks are geographically and spatially dispersed.

\section{Reduction of carbon emission}

Emissions from the agricultural sector are very substantial. Direct agricultural emissions have been increasing steadily over the last several decades in tandem with growing global agricultural production. Technical mitigation potential can be difficult to estimate precisely because agricultural emissions and mitigation have high uncertainty levels. Strategies such as restoration of degraded areas, bioenergy use, maintaining and increasing forest land would be beneficial. Use of electrical vehicles is also other choice.

\section{Forest management}

Mitigating the impact of the forest industry on the environment is crucial because, as most of human activities, it con- tributes to the loss and degradation of biosphere balances. Eucalyptus is a fast growing species which can provide the main raw material used by industry.

\section{Wind park and solar panels}

Wind turbines and photovoltaic panels may effectively modify climate of local ground level by a magnitude that could affect the 
fundamental plant-soil processes that govern carbon dynamics. Solar and wind energies have the potential to produce renewable energy across the world, although their costs currently restrict the viability in some areas.

\section{Sensing technologies}

Proximal and remote sensing sensors become robust investigation instruments of the vineyard status, such as water and nutrient availability, plant health and pathogen attacks. A lot of sensors aiming to monitor different parameters that characterize the plant growth environment are employed in precision viticulture for remote and proximal monitoring of geolocated data. Irrometers (or soil tensiometers), for example, are good indicators to control soil water content [26].

\section{Non-chemical pest management}

In the Mediterranean countries, particularly, climatic and andedaphic conditions make agricultural practices strongly dependent on the use of agrochemicals. The intensive use of agrochemicals in vines implies that high amounts of nutrients and pesticides can be transported into water bodies, with negative consequences for both the environment and public health [27]. Excessive nutrient inputs, for example, may cause degradation of water and soil quality. As many invasive plants are anticipated to benefit from climate change, the need for effective pest and disease management strategies will become more pressing in the near future. Biological control has been an effective management strategy in many instances.

\section{Conclusion}

The climate scenarios projected for many viticulture regions in the world imply that high temperatures and drought events will more frequently occur in the future. An integrated approach combining the impacts of changes in climate as well as land use is essential for a more realistic evaluation of the future state of water resources. The use of proper genotypes is the prime consideration to cope with climate change. Because of increased global air temperature along with intensity of climatic anomalies, the optimization of water use for vineyards, by improving water use efficiency, is a core subject of interest to ensure sustainability in viticulture. In cultivation, sustainable agricultural practices should be applied considering the limited sources.

\section{References}

1. Sefc KM, Steinkellner H, Lefort F, Botta R, Machado AC, et al. (2003) Evaluation of the genetic contribution of local wild vines to European grapevine cultivars. American Journal of Enology and Viticulture 54: 15-21.

2. Sabir A, Ikten H, Mutlu N, Sari D (2018) Genetic identification and conservation of local Turkish grapevine (Vitis vinifera L.) genotypes on the edge of extinction. Erwerbs-Obstbau 60(1): 31-38.

3. McGovern PE, Rudolph HM (1996) The analytical and archaeological challenge of detecting ancient wine: two case studies from the ancient Near East. In: McGovern PE, Fleming SJ, Katz SH, (Eds.), The origins and ancient history of wine. Gordon and Breach, New York, USA, pp. 57-67.

4. Zohary D, Hopf M (2000) Domestication of plants in the Old World, ( $3^{\text {rd }}$ edn), Oxford University Press, New York, USA, pp. 151-159.
5. Štajner N, Tomi'c L, Ivaniševic D, Korac N, Cvetkovic-Jovanovic T, et al. (2014) Microsatellite inferred genetic diversity and structure of Western Balkan grapevines (Vitis vinifera L.). Tree Genet Genom 10(1): 127-140.

6. Alleweldt G, Spiegel-Roy P, Reisch B (1990) Grapes (Vitis). In: Moore JN, Ballington JR (Eds.), Genetic resources of temperate fruit and nut crops. vol I. ISHS, Leuven, Belgium, pp. 291-327.

7. Winkler AJ, Cook JA, Kliewer WM, Lider LA (1974) General Viticulture. University of California Press, Berkeley, USA, pp. 710.

8. Xu X, Zhang H, Xie T, Xu Y, Zhao L, et al. (2017) Effects of climate change on the potentially suitable climatic geographical range of Liriodendron Chinese. Forests 8(10): 399.

9. van Leeuwen K, Schultz HR, Cortazar-Atauri I, Duchêne E, Ollat N, et al. (2013) Why climate change will not dramatically decrease viticultural suitability in main wine-producing areas by 2050. Proc Nat Acad Sci USA 110(33): E3051-E3052.

10. Coombe B (1987) Influence of temperature on composition and quality of grapes. ISHS Acta Horticulturae 206: 25-35.

11. Duchêne E, Schneider C (2005) Grapevine and climatic changes: A glance at the situation in Alsace. Agronomy for Sustainable Development 25(1): 93-99.

12. Mira de Orduna R (2010) Climate change associated effects on wine quality and production. Food Research International 43(7): 18441855.

13. McCarl BA (2006) US Agriculture in the climate change squeeze: Part 1: sectoral sensitivity and vulnerability. Nat Environ Trust.

14. Melloy P, Hollaway G, Luck J, Norton R, Aitken E, et al. (2010) Production and fitness of Fusarium pseudograminearum inoculum at elevated carbon dioxide in FACE. Global Change Biology 16(12): 3363-3373.

15. Rosenzweig C, Yang XB, Anderson P, Epstein P, Vicarelli M (2005) Agriculture: climate change, crop pests and diseases. In: Epstein P, Mills E, (Eds.), Climate Change Futures: Health, Ecological and Economic Dimensions. Center for Health and the Global Environment at Harvard Medical School: Boston, Massachusetts, USA, pp. 70-77.

16. Patterson DT, Westbrook JK, Joyce RJV, Lingren PD, Rogasik J (1999) Weeds, Insects, and Disease. Climatic Change 43(4): 711-727.

17. Carbonneau A (1985) The early selection of grapevine rootstocks for resistance to drought conditions. American Journal of Enology and Viticulture 36(3): 195-198.

18. Albuquerque R (1993) Réponse des cépages de Vitis vinifera L. aux variations de l'environnement: effets de la contrainte hydrique sur la photosynthèse, la photorespiration et la teneur en acide abscissique des feuilles.

19. Gabriel JL, Garrido A, Quemada M (2013) Cover crops effect on farm benefits and nitrate leaching: linking economic and environmental analysis. Agricultural Systems 121: 23-32.

20. Spinelli R, Nati C, Pari L, Mescalchin E, Magagnotti N (2012) Production and quality of biomass fuels from mechanized collection and processing of vineyard pruning residues Applied Energy 89(1): 374-379.

21. Ojeda H, Kraeva E, Deloire A, Carbonneau A, Andary C (2002) Influence of pre- and post-veraison water deficits on synthesis and concentration of skins phenolic compounds during the berry growth of Shiraz grapes (Vitis vinifera L.). American Journal of Enology Viticulture 53: 261-267.

22. Hu J, Wu J, Qu X, Li J (2018) Effects of organic wastes on structural characterizations of humic acid in semiarid soil under plastic mulched drip irrigation. Chemosphere 200: 313-321.

23. Khurshid K, Iqbal M, Arif MS, Nawaz A (2006) Effect of tillage and mulch on soil physical properties and growth of maize. International Journal of Agriculture and Biology 8(5): 593-596. 
24. Freer-Smith PH, Beckett KP, Taylor G (2005) Deposition velocities to Sorbus aria, Acer campestre, Populus deltoides X trichocarpa 'Beaupre', Pinus nigra and X Cupressocyparis leylandii for coarse, fine and ultrafine particles in the urban environment. Environ Pollut 133(1): 157167.

25. Alessandrini M, Gaiotti F, Belfiore N, Matarese F, D Onofrio C, et al (2017) Influence of vineyard altitude on Glera grape ripening (Vitis vinifera $L$.): Effects on aroma evolution and wine sensory profile. J Sci Food Agric 97(9): 2695-2705.
26. Sabir A (2016) Physiological and Morphological Responses of Grapevine (V. vinifera L. cv. 'Italia') Leaf to Water Deficit under Different Rootstock Effects. Acta Scientarum Polonorum Hortorum Cultus 15(1): 135-148.

27. Ansari AA, Naeem M, Gill SS (2018) Contaminants in Agriculture: Threat to Soil Health and Productivity. Agricultural Research and Technology 16(1): 1-2.

Your next submission with Juniper Publishers
will reach you the below assets
- Quality Editorial service
- Swift Peer Review
- Reprints availability
- E-prints Service
- Manuscript Podcast for convenient understanding
- Global attainment for your research
- Manuscript accessibility in different formats
( Pdf, E-pub, Full Text, Audio)
- Unceasing customer service
Track the below URL for one-step submission
https://juniperpublishers.com/online-submission.php

